\title{
Eating pattern and educational history in women of childbearing age
}

\author{
Syamsul Alam ${ }^{1}$, Dian Ihwana Ansyar ${ }^{2}$, M. Fais Satrianegara ${ }^{3}$ \\ ${ }^{1,2}$ Bagian Gizi Universitas Islam Negeri Alauddin \\ ${ }^{3}$ Bagian Administrasi Rumah Sakit Universitas Islam Negeri Alauddin
}

\begin{abstract}
Chronic energy deficiencies often occur and attack women of childbearing age. this illustrates insufficient energy and protein intake and it can result in health and unbalanced nutritional patterns. The purpose of this study was to determine the relationship between diet and educational history with the incidence of chronic energy deficiency in women of childbearing age in Gunturu Village, Herlang District, Bulukumba, Province of South Sulawesi. This research was conducted in 2019 with a total sample of 359 people, the design of this study was cross sectional study, data collection through interviews using questionnaires and direct observation, data of Chronic energy deficiencies obtained through LiLA measurements, consumption patterns obtained through interviews using the FFQ Form, and it was analyzed statistically with the chi square test. The result shown that the eating patterns of most respondents were in the good category and did not experience KEK. While the majority of respondents with less eating patterns did not experience KEK. Respondents who had never attended school, respondents had completed elementary / junior high / high school education, and respondents who graduated from tertiary institutions mostly did not experience KEK. The absence of a statistically significant relationship between diet and education was likely to be influenced by the proportion of WUS who experience a lower KEK that was 45 people than WUS who did not experience KEK as many as 314 people. Researchers hope that the community can maintain healthy living behaviors by managing a good diet, like watching the type of food consumed
\end{abstract}

Keyword: eating pattern; women of childbearing age; energy deficiencies

\begin{abstract}
ABSTRAK
Kekurangan energi kronik sering terjadi dan menyerang pada wanita usia subur. Hal ini menggambarkan asupan energi dan protein yang tidak cukup yang bisa berakibat pada kesehatan dan pola gizi yang tidak seimbang. Tujuan penelitian ini adalah untuk mengetahui hubungan pola makan dan riwayat pendidikan dengan kejadian kekurangan energi kronis pada wanita usia subur di Desa Gunturu, Kecamatan Herlang, Kabupaten Bulukumba, Provinsi Sulawesi Selatan. Penelitian dilakukan pada tahun 2019 dengan jumlah sampel sebanyak 359 WUS, desain penelitian cross sectional study, pengumpulan data melalui wawancara menggunakan kuesioner dan pengamatan langsung, data KEK diperoleh melalui pengukuran LILA, pola konsumsi diperoleh melalui wawancara dengan menggunakan Form FFQ, dan dianalisis secara statistik dengan uji chi square. Hasil penelitian menunjukkan bahwa pola makan sebagian besar responden adalah kategori baik dan tidak mengalami KEK. Sedangkan pola makan kurang sebagian besar tidak mengalami KEK. Responden yang pendidikannya tidak sekolah, pendidikan tamat SD/SMP/SMA dan tamat Perguruan tinggi sebagian besar tidak mengalami KEK. Tidak adanya hubungan bermakna secara statistik antara pola makan dan pendidikan dimungkinakan dipengaruhi oleh proporsi WUS yang KEK lebih kecil yaitu 45 orang daripada WUS yang tidak KEK sebanyak 314 orang. Peneliti berharap masyarakat diharapkan dapat mempertahankan perilaku hidup yang sehat dengan mengatur pola makan yang baik seperti memerhatikan jenis makanan yang dikonsumsi
\end{abstract}

Kata kunci: pola makan; usia subur; kekurangan energi

\section{PENDAHULUAN}

Kurang Energi Kronik (KEK) meru-

pakan bagian dari beberapa masalah gizi

yang masih harus dihadapi di Indonesia dan sering terjadi pada wanita usia subur (WUS). KEK adalah suatu keadaan yang menggambarkan keadaan status gizi pada wanita usia subur dimana seorang individu
Alamat Korespondensi:

Gedung FKIK Lt.1 UIN Alauddin Makassar

Email: syamsul.alam@uin-alauddin.ac.id
ISSN-P : 2086-2040

ISSN-E : 2548-5334

Volume 12, Nomor 1, Januari-Juni 2020 
mengalami kurangnya asupan zat gizi terutama energi yang dapat diakibatkan oleh kurang terpenuhinya asupan makanan sesuai angka kebutuhan gizi indivitu.

Wanita usia subur (WUS) merupakan wanita yang terdapat pada rentang umur dimana pada usia tersebut organ reproduksi wanita mulai matang dan sudah berfungsi dengan baik dengan rentang usia 15-49 tahun termasuk wanita hamil, wanita tidak hamil, ibu nifas, calon pengantin, remaja putri, dan pekerja wanita. Kekurangan energi kronik yang sering menyerang pada wanita usia subur menggambarkan asupan energi dan protein yang tidak adekuat. Salah satu indikator untuk mendeteksi risiko KEK dan status gizi pada WUS dengan melakukakan pengukuran antropometri yaitu pengukuran Lingkar Lengan bagian Atas (LILA) pada lengan tangan yang tidak sering melakukan aktifitas gerakan yang berat. Nilai ambang batas yang digunakan di Indonesia adalah nilai rerata LiLA $<23,5 \mathrm{~cm}$ yang meggambarkan terdapat resiko kekurangan energi kronik pada kelompok umur wanita usia subur (Angraini, 2018).

Pola konsumsi individu merupakan salah satu faktor penyebab langsung terhadap keadaan status gizi dan status kesehatan pada wanita usia subur. Pola konsumsi yang tidak adekuat dapat menimbulkan suatu gangguan kesehatan pada seseorang. Jika jumlah pola konsumsi ma- kanan selama satu hari tidak sesuai dengan pola gizi seimbang dan tidak sesuai dengan kebutuhan gizi individu, maka pola konsumsi tersebut terukur dalam kategori kurang baik. Gizi seimbang merupakan suatu susunan makanan sehari-hari yang mengandung zat-zat gizi dalam jenis dan jumlah yang sesuai dengan kebutuhan tubuh dan terpenuhi, dengan memerhatikan prinsip variasi makanan atau keanekaragaman, kebersihan, aktivitas fisik, dan berat badan ideal (Supariasa et al., 2002).

Menurut hasil penelitian Rahayu \& Sagita (2019) terdapat hubungan yang bermakna antara pola makan dengan kejadian kekurangan energi kronik pada ibu hamil, diperoleh nilai $\mathrm{p}$ value $=0,001$ dengan $\alpha<$ 0.05 . Pola makan yang tidak seimbang dan tidak sesuai dengan kebutuhan gizi individu menyebabkan terjadinya ketidakseimbangan asupat zat gizi yang masuk kedalam tubuh sehingga kekurangan gizi dapat terjadi pada wanita usia subur dimasa kehamilannya.

Prevalensi kurang energi kronik pada wanita usia subur, baik pada wanita hamil dan wanita tidak hamil berdasarkan hasil Riset Kesehatan Dasar (Riskesdas) Tahun 2013 menujukkan proporsi wanita usia subur dengan resiko KEK usia 15-49 tahun yang hamil sebanyak $24,2 \%$ dan yang tidak hamil sebanyak $20,8 \%$ dan terjadi penurunan prevalensi KEK berdasarkan hasil Riskesdas Tahun 2018 menjadi 17,3\% 
pada usia 15-49 tahun yang hamil dan $14,5 \%$ wanita yang tidak hamil (KEK Nasional $=31,8 \%)$. (Badan Penelitian dan Pengembangan Kesehatan, 2013, 2018). Prevalensi KEK tertinggi berdasarkan proporsi kelompok umur yaitu pada WUS yang berusia 15-19 tahun sebanyak 33,5\% pada WUS hamil dan $36,3 \%$ pada yang tidak hamil. Prevalensi KEK provinsi Sulawesi Selatan masih diatas angka rata-rata nasional yaitu 34,59\% dengan prevalensi KEK pada WUS yang hamil sebanyak $16,87 \%$ pada $17,72 \%$ pada WUS yang tidak hamil. Sedangkan di Kabupaten Bulukumba menujukkan prevalensi KEK pada wanita tidak hamil masih diatas angka nasinali yaitu sebanyak 17,46\% (Badan Penelitian dan Pengembangan Kesehatan, 2018).

Penelitian ini bertujuan untuk mengetahui adanya hubungan antara pola makan dan riwayat pendidikan dengan kejadian kekurangan energi kronik pada wanita usia subur di Desa Gunturu, Kecamatan Herlang, Kabupaten Bulukumba, Provinsi Sulawesi Selatan

\section{METODE PENELITIAN}

Rancangan penelitian yang digunakan adalah observasional analitik, dengan desain secara cross sectional study (potong lintang), data penelitian yang diperoleh melalui pengumpulan data dilapangan di- analisis dengan statistik. Sampel pada penelitian ini adalah semua wanita usia subur yang berusia 15-49 tahun 2019 yang bersedia jadi responden di Desa Gunturu Kec.Herlang Kab.Bulukumba yang berjumlah 359 dengan teknik sampling yaitu exhaustic sampling dimana jumlah populasi sama dengan jumlah sampel.

Pengumpulan data primer melalui wawancara dengan menggunakan kuesioner, formulir Food Frequency Questionnaire (FFQ) dan pengukuran antropometri. Data karakteristik sampel diperoleh melalui wawancara terhadap responden dengan menggunakan kuesioner, data KEK diperoleh melalui pengukuran lingkar lengan atas pada lengan responden yang tidak sering digunakan secara dominan dalam melakukan aktivitas berat, data pola konsumsi satu bulan terakhir diperoleh melalui wawancara terhadap responden dengan menggunakan isian formulir Food Frequency Questionnaire (FFQ). Data dianlisis secara statistik dengan uji chi square, untuk mengetahui kemaknaan hubungan antar variabel dimana memiliki kemaknaan jika nilai $\mathrm{p} \leq 0,05$ dengan tingkat kepercayaan $95 \%$.

\section{HASIL PENELITIAN}

Berdasarkah hasil penelitian pada tabel 1, menunjukan bahwa sebagian besar responden menyelesaikan pendidikan 
dengan tamat SD/SMP/SMA sebanyak $74,4 \%$, tamat perguruan tinggi sebanyak $14,7 \%$ dan tidak sekolah sebanyak 10,6\%. Responden yang tidak bekerja bekerja atau tidak melalukankan kegiatan pekerjaan yang dapat menambah penghasilan keluarga sebanyak $77,2 \%$ dan yang bekerja hanya $22,8 \%$. Pola makan pada wanita usia subur lebih rendah berdasarkan hasil laporan Riskesdas Tahun 2018 yaitu prevalesi KEK provinsi Sulawesi Selatan sebesar 17,72\% dan prevalensi KEK di Kabupaten Bulukumba yaitu 17,46\%.

Pada tabel 2 menggabarkan hubungan variebel independen yang mempengaruhi kejadian KEK pada wanita usia subur di

Tabel 1. Karakteristik Responden

\begin{tabular}{lcc}
\hline \multicolumn{1}{c}{ Variabel } & $\mathrm{n}=(359)$ & Persentase \\
\hline Pendidikan & & $10,6 \%$ \\
Tidak Sekolah & 38 & $74,7 \%$ \\
Tamat SD/SMP/SMA & 268 & $14,7 \%$ \\
Tamat Perguruan Tinggi & 53 & \\
Status Pekerjaan & & $22,8 \%$ \\
Bekerja & 82 & $77,2 \%$ \\
Tidak Bekerja & 277 & \\
Pola Makan & & $39,6 \%$ \\
Baik & 142 & $60,4 \%$ \\
Kurang & 217 & \\
Kekurangan Energi Kalori (KEK) & & $87,5 \%$ \\
Normal & & $12,5 \%$ \\
KEK & 314 & \\
\hline
\end{tabular}

Sumber: Data Primer, 2019

di desa Gunturu sebagian besar kategori kurang yaitu sebanyak $60,4 \%$ dan yang berkategori baik sesuai dengan angka kebutuhan gizi individu sebanyak 39,6\%. Berdasarkan hasil pengukuran lingkar lengan atas (LILA), responden yang mengalami kekurangan energi kronik hanya 12,5\%., ini menggambarkan bahwa sebagian besar wanita usia subur di Desa Gunturu tidak mengalami keurangan energi kronik dan prevalnsi KEK pada wilayah tersebut masih
Desa Guntur, Kab. Bulukumba. Hasil penelitian menunjukkan pola makan responden yaitu dari 142 sampel yang pola makan baik terdapat 125 orang $(88.0 \%)$ yang termasuk dalam kategori LILA normal dan 17 orang ( $12.0 \%$ ) mengalami KEK. Sedangkan dari 217 sampel yang pola makan kurang terdapat 189 orang $(87.1 \%)$ yang termasuk dalam kategori LILA normal dan 28 orang ( $12.9 \%$ ) mengalami KEK. Berdasarkan hasil analisa dengan uji statis- 
tic Pearson Chi Square diperoleh nilai $\mathrm{p}$ $=0,794>(\alpha=0,05) . \quad$ Sedangkan variabel riwayat pendidikan diperoleh data bahwa dari 38 sampel yang pendidikannya tidak sekolah terdapat 35 orang $(92.1 \%)$ normal dan 3 orang ( $7.9 \%$ ) mengalami KEK. Dari 268 sampel pendidikan tamat SD/SMP/SMA terdapat 232 osrang (86.6 \%) yang termasuk dalam kategori normal dan 36 orang ( $13.4 \%$ ) mengalami KEK. Dan dari 53 sampel yang berpendidikan tamat PT terdapat 47 orang $(88.7 \%)$ normal dan 6 orang ( $11.3 \%)$ mengalami KEK. Berdasarkan hasil analisa dengan uji statistic Pearson Chi Square diperoleh nilai ungan bermakna antara pola makan dan riwayat pendidikan (nilai $\mathrm{p}>0,05$ ) dengan kejadian Kurang Energi Kronik (KEK) pada Wanita Usia Subur (WUS) di Desa Gunturu, Kec. Herlang, Kab. Bulukumba.

\section{PEMBAHASAN}

Kerurangan energi kronik yang terjadi pada wanita unsia subur merupakan akibat dari faktor tidak langsug seperti lingkungan dan faktor langsun dari individu manusia yang didukung oleh konsumsi zat gizi sesuai kebutuhan, maka zat gizi yang tersimpan dalam tubuh digunakan untuk memenuhi kebutuhan. Apabila keadaan terse-

Tabel 2. Pengaruh Pola Makan dan Riwayat Pendidikan Terhadap Kejadian KEK

\begin{tabular}{|c|c|c|c|c|c|}
\hline \multirow{3}{*}{ Faktor yang Mempengarhui } & \multicolumn{4}{|c|}{$\begin{array}{c}\text { Kejadiaan KEK } \\
(n=359)\end{array}$} & \multirow{3}{*}{ P-Value } \\
\hline & \multicolumn{2}{|c|}{ Normal } & \multicolumn{2}{|c|}{ KEK } & \\
\hline & $\mathrm{N}$ & $\%$ & $\mathrm{~N}$ & $\%$ & \\
\hline \multicolumn{6}{|l|}{ Pola Makan } \\
\hline Baik & 125 & 88,0 & 37 & 12,0 & \\
\hline Kurang & 189 & 87,1 & 8 & 12,9 & $\mathrm{P}=0,794$ \\
\hline \multicolumn{6}{|l|}{ Riwayat Pendidikan } \\
\hline Tidak Sekolah & 35 & 92,1 & 3 & 7,9 & \\
\hline Tamat SD/SMP/SMA & 232 & 86,6 & 36 & 13,4 & $\mathrm{P}=0,602$ \\
\hline Tamat PT & 47 & 88,7 & 6 & 11,3 & \\
\hline
\end{tabular}

Sumber: Data Primer, 2019

$p=0,602>(\alpha=0,05)$.

Pada tabel 2 menunjukkan hasil analisis data statistik dengan menggunakan uji chi-square dari penelitian tersebut, menujukkan bahwa tidak terdapat hub- but terus berlangsung dalam jangka waktu lama, maka simpanan zat gizi digunakan sebagai sumber energi dan akan habis, yang pada akhirnya terjadi kemerosotan jaringan dalam tubuh. 
Penelitian ini dilakukan di Desa Gunturu selama kurag lebih empat belas hari dengan cara pengumpulan data secara langsung pada responden dengan menggunakan kuesioner dan pengukuran LILA pada 359 sampel yang bersedia diwanwacarai. Hasil penelitian menunjukkan bahwa, terdapat $87.5 \%$ sampel dengan LILA normal dan $12.5 \%$ mengalami KEK. Status gizi baik pada wanita usia subur adalah suatu keadaan dimana asupan zat gizi sesuai penggunaannya untuk aktivitas tubuh. Refleksi yang diberikan dalam tubuh terjadi keselarasan antara pertumbuhan berat badan dan tinggi badan sesuai dengan umur seseorang. Berdasarkan hasil identifikasi hasil pengukuran LILA responden kemudian diketahui bahwa responden dengan ukuran LILA normal lebih banyak daripada responden yang mengalami KEK, diketahui lebih lanjut bahwa sebagian besar responden yang LILAnya normal dengan status tidak bekerja diluar rumah atau sebagai ibu rumah tangga dan tidak menambah penghasilan keluarga.

Berdasarkan data hasil penelitian, didapatkan bahwa dari 359 sampel sebagian besar frekuensi pola makan responden dengan kategori kurang sebanyak 217 orang ( $60.4 \%$ ) yang artinya lebih dari standart. Hasil analisa dengan uji statistic Pearson Chi Square didapatkan tidak ada hubungan antara Pola Makan dengan ke- jadian Kurang Energi Kronik (KEK) pada Wanita Usia Subur (WUS) di Desa Gunturu Kec Herlang Kab Bulukumba dengan nilai $p=0,794>(\alpha=0,05)$. Penelitian ini juga menunjukkan bahwa dari 142 responden dengan kategori pola makan baik baik sebanyak 125 orang $(88.0 \%)$ yang termasuk dalam kategori LILA normal dan 17 orang ( $12.0 \%$ ) mengalami KEK. Sedangkan dari 217 sampel yang pola makan kurang terdapat yang termasuk dalam kategori LILA normal dan 28 orang ( $12.9 \%$ ) mengalami KEK. Hal tersebut dapat terjadi dikarenakan pola makan bukanlah merupakan suatu faktor tunggal yang menyebabkan terjadinya KEK pada Wanita Usia Subur (WUS). Pada penelitian ini, ditemukan Wanita Usia Subur (WUS) tidak mengalami KEK namun pola makannya dengan kategori kurang baik. Kondisi tersebut perlu menjadi perhatia utama pada Wanita Usia Subur (WUS) karena dapat berdampak pada kesehatannya terutama pada WUS dalam keadaan hamil. WUS dengan pola makan kategori kurang dapat diindikasikan bahwa WUS tersebut tidak tercukupi kebutuhan nutrisinya sesuua angka kebutuhan gizi yang direkomendasikan sehingga berpotensi terjadinya ganggunng gizi atau kekurangan gizi. Kebiasaan pola makan yang kurang memenuhi standar, jika berlangsung lama maka WUS akan berisiko mengalami KEK dibandingkan mereka dengan pola makan 
yang baik, meskipun pada saat penelitian keadaan Wanita Usia Subur (WUS) dikategorikan tidak mengalami KEK.

Berdasarkan data yang diperoleh saat penelitian, menunjukka bahwa lebih banyak Wanita Usia Subur (WUS) yang sehari- harinya sebagai ibu rumah tangga. Hal tersebut mengindikasikan aktifitas fisik yang dilakukan sebagai seorang ibu rumah tangga cenderung lebih ringan daripada ibu yang bekerja di luar rumah dengan kapasitas pekerjaan yang membutuhkan lebih banyak energi. Kegiatan aktifitas fisik dapat mengurangi pembakaran energi dalam tubuh yang dapat mengurangi cadangan energi di dalam tubuh Wanita Usia Subur (WUS). Tingkat aktifitas fisik seseorang dapat berkaitan dengan rutinitas kegiatan yang dilakukan setiap harinya. Seseorang dengan tingkat aktifitas yang berat setiap harinya dan tidak diimbangi dengan asupan makan yang adekuat dapat mengakibatkan terjadinya kekurangan energi kronik dan tubuhnya lebih rentan terkena penyakit infeksia. (Wardhani, 2020)

Pada penelitian ini, adanya Wanita Usia Subur (WUS) yang pola makannya dengan kategori baik namun mengalami KEK dapat diindikasikan bahwa asupan makanan yang dikonsumsi oleh responden tidak adekuat terhadap kebutuhan tubuh Wanita Usia Subur (WUS) pada kondisi tertentu. Konsumsi makanan yang adekuat pada Wanita Usia Subur (WUS) adalah makanan yang dikonsumsi tiap harinya dapat memenuhi kebutuhan zat gizi yang diperlukan oleh tubuh yang terpenuhi baik secara kualitas maupun kuantitasnya. Temuan penelitian ini sejalan dengan penelitian Putri (2017) yang menunjukkan bahwa pola makan tidak berhubungan dengan kurang energi kronis (KEK) pada Wanita Usia Subur (Wus) Di Kecamatan Terbanggi Besar Kabupaten Lampung Tengah didapatkan $\mathrm{p}$-value $0,589(\mathrm{p}>0,05)$. Namun, temuan penelitian Precelia Ika pada siswa SMA di Bogor menunjukkan adanya hubungan antara frekuensi makan dengan KEK dengan p-value 0,000 (p > 0,05) dan jenis ragam makanan dengan KEK dengan $p$-value $0,000(p>0,05)$. Dari kedua variabel disimpulkan bahwa kejadian KEK dipengarhui oleh pola makan remaja putri di SMA 6 Bogor tahun 2019.

Herbold \& Edelstein (2012) mengemukakan bahwa faktor yang berhubungan dengan pola makan salah satunya adalah tingkat pengetahuan seseorang. Tingkat pengetahuan pada WUS sangat mempengaruhi terhadap pola konsumsi dalam kehidupannya. WUS yang mengetahui dan paham mengenai pentingnya nutrisi bagi kebutuhan tubuhnya, maka WUS tersebut memilik kesadaran yang tinggi tentang pentingnya berpola makan yang baik. 
Keadaan gizi Wanita Usia Subur (WUS) bisa dipengaruhi oleh ketidakseimbangan asupan jenis dan variasi makanan yang dikonsumsi, kandungan zat gizi, porsi makanan dan frekuensinya, tingkat kepercayaan dan penerimaan terhadap makanan misalnya : pantangan makan dan rasa suka atau tidak suka terhadap suatu makanan. Hal inilah yang dapat mempegaruhi status gizi pada Wanita Usia Subur (WUS) dan kondisi tersebut cenderung menyebabkan kekurangan zat gizi tertentu seperti $\mathrm{Ku}-$ rang Energi Kronik (KEK).

Pada penelitian ini menunjukkan riwayat pendidikan responden dikategorikan menjadi tiga, yaitu tidak tamat sekolah, Tamat SD/SMP/SMA, dan Tamat PT . Hasil analisais statistic dengan uji Pearson Chi Square menunujukkan bahwa tidak ada hubungan antara riwayat pendidikan dengan kejadian Kurang Energi Kronik (KEK) pada Wanita Usia Subur (WUS) di Desa Gunturu Kec Herlang Kab Bulukumba dengan nilai $\mathrm{p}=0,602$. Hal ini ditunjukkan pada tabel 2 bahwa kecenderungan kejadian KEK pada WUS lebih banyak pada responden yang tingkat pendidikannya tamat SD/SMP/SMA yaitu sebesar $13.4 \%$ Begitupun sebaliknya, terdapat $88.7 \%$ WUS tidak mengalami KEK yang pendidikan terakhirnya tamat perguruan Tinggi. Hasil penelitian ini juga menunjukkan bahwa terdapat sampel yang pendidikannya tamat SD/SMP/SMA dan memiliki ukuran LILA normal hal ini sangat bertentangan dengan teori bahwa tingkat pendidikan yang rendah memungkinkan rendahnya pengetahuan responden tentang pentingnya asupan gizi seimbang untuk kesehatan tubuh. Keadaan tersebut sesuai dengan temuan penelitian (Saraswati et al., 2019), bahwa ibu hamil dengan pendidikan tamat SMP memiliki risiko kecil menderita KEK dibandingkan ibu hamil yang berpendidikan tamat SD.

Riwayat pendidikan seseorang meupakan suatu unsur penting yang dapat mempengaruhi status gizi dan kesehatannya. Masalah gizi dan kesehatan seringkali terjadi karena adanya ketidaktahuan dan kurang informasi tentang penting pemenuhan gizi untuk kesehatan tubuh sehingga berdampak pada kesadaran dan kemauan berperilaku gizi seimbang dalam kehidupannya. Fakta lapangan ditemukan banyaknya responden dengan tingkat pendidikan tinggi, memiliki pekerjaan yang mapan, mempunyai fasilitas rumah yang memadai namun responden tersebut berisiko KEK. Hal yang mungkin menyebabkan ini terjadi adalah seseorang dengan pendidikan rendah belum tentu kurang mampu menyusun makanan yang memenuhi persyaratan gizi dibandingkan dengan orang lain yang tingkat pendidikannya tinggi. Sekalipun berpendidikan rendah jika orang tersebut mendengarkan atau melihat informasi 
mengenai pemenuhan gizi untuk kesehatan tubuh, cenderung pengetahuan gizinya menjadi lebih baik dan mampu mempraktekknaya dalam pemenuhi gizinya, begitupun sebaliknya mereka dengan status pendidikan yang baik namun kurang mampu menyusun makanan yang memenuhi persyaratan gizi sesuai yang dianjurkan, inilah yang beresiko terjadinya keurangan gizi seperti KES pada WUS. Penyebabnya bisa jadi karena pendidikan yang memadai sehingga peluang beraktifitas diluar rumah lebih besar sehingga berdampak pada beban kerja yang membuat merasa lebih stres, pola hidup dan pola makan yang tidak teratur sehingga tidak mustahil jika responden dapat berisiko Kekurangan Energi Kronik (Kartikasari et al., 2012).

Temuan penilian ini sejalan dengan penelitian yang dilakukan oleh Mahirawati (2014) bahwa tidak ada hubungan yang bermakna antara Pendidikan dengan Kekuarangan Energi Kronik (KEK) pada ibu hamil, di Kec. Kamoning dan Temblengan Kab. Semarang, Prov. Jawa Timur yang menunjukkan dengan nilai $\mathrm{p}=0,134$. Sama halnya dengan temuan penelitian yang dilakukan oleh Siahaan et al., (2017) di Puskesmas Sei Jang Kecamatan Bukit Bestari Kota Tanjung Pinang, menyatakan bahwa tidak ada hubungan yang antara variabel pendidikan dengan Kekurangan Energi Kronik (KEK) pada Ibu Hamil, dengan nilan $\mathrm{p}=0,561$.

\section{KESIMPULAN}

Berdasarkan hasil penelitian, menunjukkan tidak terdapat hubungan antara pola makan dan riwayat pendidikan dengan kejadian KEK pada Wanitas Usia Subur di Desa Gunturu Kab. Bulukumba. Tidak adanya hubungan bermakana secara statistik antara pola makan dan riwayat pendidikan dimungkinakan dipengaruhi oleh proporsi WUS yang KEK lebih kecil yaitu 45 orang (12,5\%) daripada WUS yang tidak KEK sebanyak 314 orang $(85,5 \%)$.

\section{SARAN}

Dengan masih banyaknya kejadian KEK pada ibu hamil, masyarakat diharapkan mulai menyusun perilaku hidup yang sehat dengan mengatur pola makan yang baik seperti jenis makanan yang dimakan agar menjadi perhatian sehingga tidak terjadi kembali pada saat kehamilan selanjutnya. Untuk meningkatkan keinginan makan, sebaiknya ibu hamil menambah variasi penyajian menu makanan seharihari. Penggantian jenis makanan tertentu dengan jenis makanan lain dengan kandungan gizi yang sama bisa digunakan untuk memenuhi kebutuhan gizi ibu hamil dengan pendapatan keluarga yang cukup atau kurang. Institusi Kesehatan sebaiknya memperbanyak program inovatif untuk me- 
nanggulangi KEK dengan mengakaji secara mendalam penyebab KEK di wilayah setempat sehingga pemecahan masalah yaang diberikan bisa tepat sasaran. Intitusi Kesehatan sebaiknya menerapkan secara aktif KIE pada ibu hamil terutama tentang nutrisi pada kehamilan khususnya mengenai Kekurangan Energi Kronik atau KEK. Kerjasama lintas sektor antara pemerintah denga dinas kesehatan secara berkelanjutan juga diperlukan untuk melakukan pemeriksaan terhadap ibu hamil agar dapat melakukan tindakan pencegahan terhadap ibu hamil yang berisiko KEK. Peneliti selanjutnya diharapkan mengembangkan penelitian dengan menambah variabel bebas yang lain untuk menggali penyebab KEK di wilayah setempat.

\section{DAFTAR PUSTAKA}

Angraini, D. I. (2018). Hubungan Faktor Keluarga dengan Kejadian Kurang Energi Kronis pada Wanita Usia Subur di Kecamatan Terbanggi Besar. JK Unila, 2(2), 146-150. https://juke.kedokteran.unila.ac.id/ind ex.php/JK/article/download/1952/191 9

Badan Penelitian dan Pengembangan Kesehatan. (2013). Laporan Riset Kesehatan Dasar.

Badan Penelitian dan Pengembangan Kesehatan. (2018). Laporan Riset Kesehatan Dasar.

Herbold, N., \& Edelstein, S. (2012). Buku Saku Nutrisi.
Kartikasari, B. W., Mifbakhuddin, \& Mustika, D. N. (2012). Hubungan Pendidikan, paritas, dan Pekerjaan Ibu Dengan Status Gizi Ibu Hamil Trimester III di Puskesmas Bangetayu Kecamatan Genuk Kota Semarang Tahun 2011. Jurnal Kebidanan, 1(1), 2.

https://doi.org/https://doi.org/10.2671 4/jk.1.1.2012.9-18

Mahirawati, V. K. (2014). Faktor-faktor yang berhubungan dengan kekurangan Energi Kronik (KEK) pada ibu hamil di Kecamatan Kamoning dan Tambelangan, Kabupaten Sampang, Jawa Timur (Related Factors of chronic Energy Deficiency at Pregnant Woman in kamoning and Tambelangan Sub Distri. Buletin Penelitian Sistem Kesehatan, 17(2 Apr), 193-202. https://doi.org/10.22435/bpsk.v17i2A pr.3609

Putri, M. C. (2017). Hubungan Asupan Makan Dengan Kejadian Kurang Energi Kronis ( KEK ) Pada Wanita Usia Subur ( WUS ) Di Kecamatan Terbanggi Besar Kabupaten Lampung Tengah. Lampung.

Rahayu, D. T., \& Sagita, Y. D. (2019). Pola Makan Dan Pendapatan Keluarga Dengan Kejadian Kekurangan Energi Kronik ( KEK ) Pada Ibu Hamil Trimester II. 13(1), 7-18.

Saraswati, P. S., Tasnim, T., \& Sunarsih, S. (2019). Pengaruh Media Whatsapp Dan Leaflet Terhadap Perilaku Pemeriksaan Payudara Sendiri Pada Siswi Sekolah Menengah Atas Di Kota Kendari. Al-Sihah: The Public Health Science Journal, 11(2). https://doi.org/10.24252/AS.V11I2.96 62

Siahaan, G. M., Widajanti, L., \& Aruben, R. (2017). Hubungan sosial ekonomi dan asupan zat gizi dengan kejadian ku- 
rang energi kronik (KEK) pada ibu hamil di wilayah Puskesmas Sei Jang Kecamatan Bukit Bestari Kota Tanjung Pinang tahun 2016. Jurnal Kesehatan Masyarakat, 5(3), 138147.

https://ejournal3.undip.ac.id/index.ph $\mathrm{p} / \mathrm{jkm} / \mathrm{article} / \mathrm{view} / 17184$

Supariasa, I. D. N., Bakri, B., \& Fajar, I. (2002). Penilaian Status Gizi (2nd ed.). Buku Kedoktran EGC.

Wardhani, P. I. (2020). Hubungan body image dan pola makan dengan kekurangan energi kronis (KEK) pada remaja putri di SMAN 6 Bogor tahun 2019. Journal of Public Health Research and Community Health Development, $3(2), \quad 128$. https://doi.org/10.20473/jphrecode.v3 i2. 14527 